$\mathrm{DE}$

M E D I C I N A

T R O P I C A L

$\mathrm{DE}$

SÃO PAULO

JOURNAL OF THE SÃO PAULO INSTITUTE OF TROPICAL MEDICINE

1 Universidade Federal do Amazonas, Escola de Enfermagem de Manaus, Manaus, Amazonas, Brazil

${ }^{2}$ Fundação Oswaldo Cruz, Instituto Leônidas e Maria Deane, Manaus, Amazonas, Brazil

Correspondence to: Maria Jacirema Ferreira Gonçalves

Fundação Oswaldo Cruz, Instituto Leônidas e Maria Deane, Rua Terezina, 476, Arianópolis, CEP 69057-070, Manaus, AM, Brazil

E-mail: jaciremagoncalves@gmail.com

Received: 21 November 2018

Accepted: 12 March 2019

\section{American Tegumentary Leishmaniasis in the Brazilian Amazon from 2010 to 2014}

\author{
Giovana da Costa Teles ${ }^{(i)}$, Fernanda Rodrigues Fonseca ${ }^{(i)}$, Maria Jacirema \\ Ferreira Gonçalves ${ }^{(1,2}$
}

\section{ABSTRACT}

American tegumentary leishmaniasis (ATL) is one of the most important but neglected infectious diseases, and can cause severe deformities. ATL incidence remains high in forest regions, such as in the Amazonas State, Brazil. However, differences within the State and over time have been observed, since infection patterns are not homogeneous, and these aspects need to be clarified. This study aimed to identify the epidemiological profile of ATL and its spatial and temporal distribution in the Brazilian Amazon, from 2010 to 2014. Data were extracted from the Information System for Notifiable Diseases, which descriptively evaluates the incidence rate, as well as the temporal and spatial distribution of the disease. The highest prevalence of ATL was found in men and in the age group of 20-40 years. Approximately $95 \%$ of the cases were of cutaneous ATL and they were identified through direct examination. The spatial analysis has shown that ATL was widely distributed, both in rural and urban areas, and more concentrated in the Southern part of the State. Moreover, although there was an expansion in the spatial distribution and an increasing incidence of ATL in Amazonas, the epidemiological profile remained unchanged, suggesting that other factors must be responsible for its widespread distribution and increasing incidence.

KEYWORDS: Cutaneous leishmaniasis. Epidemiology. Neglected diseases.

\section{INTRODUCTION}

American tegumentary leishmaniasis (ATL) is a zoonotic disease caused by the protozoan Leishmania, which affects both humans and animals. It is an infectious disease with chronic evolution and is classified in several clinical forms: cutaneous, mucosal and mucocutaneous ${ }^{1}$.

ATL, a neglected disease ${ }^{2}$, is a public health problem that requires attention and is classified as one of the six infectious diseases of great importance owing to its high detection coefficient and characteristics that cause deformities. Due to the occurrence of lesions, ATL can compromise the patient's psychological state, besides affecting social and economic status, as it is also considered an occupational disease ${ }^{3}$.

Brazil is one of the five main countries with the highest incidences of ATL worldwide ${ }^{4}$. The epidemiology of ATL has been continuously changing in recent years, since it was primarily characterized as a zoonosis transmitted to humans when they came into contact with the vectors in forests. However, ATL has also started to emerge in deforested rural and peri-urban areas ${ }^{1}$. This situation may be explained by the presence of various vectors, reservoirs and etiological agents, together with socioeconomic and environmental conditions, such as unplanned urbanization, 
deforestation and population concentration, which can contribute to changes in the disease cycle ${ }^{4}$.

Amazonas is the Brazilian State with the highest incidence of ATL, with Leishmania (Viannia) guyanensis as the etiologic agent. In addition, ATL has recently become widespread with an increased incidence in the State, especially in municipalities previously free of the disease ${ }^{5}$. However, there have been few attempts at scientific evaluation in the scientific world, media and general society and as it is a severe disease that can cause suffering and increase economic burden, it calls for the attention of health services ${ }^{6}$.

It is important to provide information that could be used to manage and control the disease in endemic areas. This is the focus of the epidemiological surveillance, because there is no objective method, such as a vaccine, for preventing this disease. Health education is required to create awareness among populations in order to promote the avoidance of areas with epidemic outbreaks, and for those in areas at risk, to promote the use of preventive strategies, such as repellents, mosquito nets, window and door screens and environmental management to avoid vector contact. Therefore, this study aimed to identify the epidemiological profile of ATL and its spatial and temporal distributions in Amazonas, from 2010 to 2014.

\section{MATERIAL AND METHODS}

\section{Study design}

This was an epidemiological, observational and ecological study, performed using the ATL data annually reported by the Information System of Notifiable Diseases (SINAN), focusing on epidemiological, spatial and temporal distribution.

\section{Study area}

The study area was the entire Amazonas State, the largest State in Brazil, with an area of 1,559,146.876 km ${ }^{2}$ but low population density $(3,873,743 \text { inhabitants })^{8}$, corresponding to 2.5 inhabitants $/ \mathrm{km}^{2}$ in 2014 . However, this State has the highest incidence of ATL, with an average of 50 cases $/ 100,000$ inhabitants compared to the 10.4 cases $/ 100,000$ inhabitants recorded in the entire country in $2014^{9}$.

\section{Study population and data source}

The study population consisted of all newly diagnosed cases of ATL reported to SINAN in Amazonas (Brazilian Amazon), from January 1 $1^{\text {st }}, 2010$, to December 31 ${ }^{\text {st }}, 2014$.
Annual ATL data from SINAN were obtained from the Ministry of Health, without individual identification (updated on September 21 $1^{\text {st }}, 2015$ ). Therefore, these were secondary data, and approval from the research ethics committee for studies involving human participants was thus not required, according to the National Health Council, Resolution 510/2016 ${ }^{10}$. Each row in the database corresponds to a case; the cases were grouped according to municipality for the analysis, as well as in appended databases according to the year of notification.

Annual population estimates were recorded in the Department of Information of Unified Health System (Datasus) and were obtained at the municipal level ${ }^{11}$.

\section{Variables}

The data were analyzed by: 1) demographic profile (sex, age, years of education and ethnicity). The classification of ethnicity or skin color followed the guidelines of the Brazilian Institute of Geography and Statistics (IBGE). People are asked to classify themselves based on their skin color; hence, we adopted the terms Black, Yellow, White, Mixed Ethnicity (Black and White) and Indigenous ${ }^{12}$. In this analysis we grouped individuals into mixed ethnicity and not mixed ethnicity groups, since the majority of the population, and consequently, the cases, belonged to this group; 2) clinical aspect, diagnosis, and follow-up (ATL clinical form, HIV-ATL coinfection, and diagnostic exams, such as direct parasitology [biopsy of the lesion whose material is used to make a smear on a slide, which is then stained with Giemsa] ${ }^{3}$, Montenegro intradermic reaction, and histopathology); 3) geographical aspects (municipality, urban/rural housing area and epidemiological classification [autochthonous/imported]); and 4) ATL burden: annual incidence rate, obtained using the following formula:

$$
\frac{\text { New cases per year }}{\text { Population per year }} \times 100,000 \text { inhabitants }
$$

\section{Data analysis}

Descriptive statistics were used to summarize the data, presenting the percentage of the annualized distribution of the variables. The incidence rate was stratified into five categories, according to the mean rate from 2010 to 2014 for all municipalities: up to $25 ;>25$ to $<=50 ;>50$ to $<=100$; $>100$ to $<=200$; and $>200$. These ATL cutoff points followed the exploratory analysis in which a similar interquartile distribution of the rate, in most years, was found. For each category of ATL rate, we obtained the median and quartile in order to understand the evolution of the disease; we have 
also obtained the median for each year. The median was used since the distribution of the annual rates of ATL was not normal according to the Shapiro-Wilk test. The spatial distribution was calculated by mapping the crude annual incidence rates of ATL in Amazonas (Brazilian Amazon). The spatial results are presented in thematic maps created using Q-Gis ${ }^{\circledR}$ free software, version 2.16.

\section{RESULTS}

ATL was predominantly found in men, comprising approximately $80 \%$ of all reported cases. It is important to note that the Demographic Census of the IBGE in 2010 registered 1,822,607 $(50.6 \%)^{8} \mathrm{men}$ in the Amazonas State, which reinforces the magnitude of the higher burden of infection in males. It was also mainly observed in adults between 20 and 40 years old, with mixed ethnicity (black and white) and low educational level. In several cases, schooling data were missing or incomplete (Table 1).

Regarding the clinical aspects, for all the analyzed years, the proportion of cutaneous ATL was greater than $95 \%$. No records of mixed forms (mucocutaneous) were found. The occurrence of HIV-ATL coinfection was low ( $<1 \%$ throughout the study period), but HIV tests were not performed in more than half of the cases, except in 2010. Direct parasitological examination was performed in approximately $90 \%$ of the cases. Regarding geographical aspects, ATL was found in both rural and urban areas. This clearly indicated that the transmission pattern of the disease was not only wild, but also autochthonous, corresponding to approximately $75-80 \%$ of all cases (Table 2 ).

\section{Temporal distribution}

The temporal distribution showed that ATL incidence increased from 2010 to 2011, remained constant in 2012, decreased during 2012 and 2013, and increased in 2013 and 2014 (Figure 1). In the category $>200$, the median incidence rate has shown oscillations, with an increase in 2011 and reduction in subsequent years, increasing again in 2014. The opposite behavior was observed in the stratum $>100$ to 200, with a pronounced increase in the year 2013. In the other strata, the median incidence rate was similar across all years (Table 3 ).

Table 1 - Distribution of demographic characteristics of new American tegumentary leishmaniasis cases in Amazonas, $2010-2014$.

\begin{tabular}{|c|c|c|c|c|c|c|}
\hline Description & $\begin{array}{c}2010 \\
\mathrm{n}=1,089 \\
\%\end{array}$ & $\begin{array}{c}2011 \\
\mathrm{n}=2,112 \\
\%\end{array}$ & $\begin{array}{c}2012 \\
\mathrm{n}=2,077 \\
\%\end{array}$ & $\begin{array}{c}2013 \\
\mathrm{n}=1,361 \\
\%\end{array}$ & $\begin{array}{c}2014 \\
\mathrm{n}=1,745 \\
\%\end{array}$ & $\begin{array}{c}\text { Total cases } \\
\mathrm{n}=8,384\end{array}$ \\
\hline \multicolumn{7}{|l|}{ Sex } \\
\hline Male & 81.6 & 81.3 & 78.6 & 78.5 & 78.5 & 6,675 \\
\hline Female & 18.4 & 18.7 & 21.4 & 21.5 & 21.5 & 1,709 \\
\hline \multicolumn{7}{|l|}{ Age group (years) } \\
\hline$<1$ & 1.3 & 1.0 & 0.9 & 1.1 & 1.7 & 98 \\
\hline 1 to 14 & 14.3 & 13.0 & 16.7 & 16.2 & 15.5 & 1,268 \\
\hline 15 to 19 & 13.6 & 12.0 & 13.7 & 12.0 & 14.1 & 1,097 \\
\hline 20 to 29 & 31.5 & 28.1 & 25.7 & 24.7 & 24.1 & 2,227 \\
\hline 30 to 39 & 20.3 & 21.4 & 18.1 & 21.1 & 19.7 & 1,678 \\
\hline 40 to 49 & 9.3 & 14.6 & 13.0 & 11.8 & 12.7 & 1,019 \\
\hline 50 or more & 9.7 & 11.9 & 11.9 & 13.2 & 12.2 & 997 \\
\hline \multicolumn{7}{|l|}{ Years of schooling } \\
\hline 0 to 8 & 58.7 & 40.4 & 43.0 & 41.3 & 35 & 3,151 \\
\hline 9 or more & 12.9 & 10.9 & 11.0 & 18.1 & 14.5 & 1,508 \\
\hline Not applicable & 5.4 & 5.1 & 4.6 & 5.0 & 5.0 & 421 \\
\hline Ignored/missing data & 22.9 & 43.5 & 41.3 & 35.5 & 45.5 & 3,304 \\
\hline \multicolumn{7}{|l|}{ Skin color/ethnicity* } \\
\hline Mixed (Black and White) & 67.9 & 82.5 & 82.6 & 82.1 & 83.1 & 6765 \\
\hline Not mixed/others & 32.1 & 17.5 & 17.4 & 17.9 & 16.9 & 1619 \\
\hline
\end{tabular}

Source: Information System of Notifiable Diseases (SINAN). *Classification based on the Brazilian Institute of Geography and Statistics, which considered skin color and ethnicity as synonymous. 
Table 2 - Clinical and geographic annual percentage distribution of new American Tegumentary Leishmaniasis cases in Amazonas, 2010-2014.

\begin{tabular}{|c|c|c|c|c|c|c|}
\hline Description & $\begin{array}{c}2010 \\
\mathrm{n}=1,089 \\
\%\end{array}$ & $\begin{array}{c}2011 \\
\mathrm{n}=2,112 \\
\%\end{array}$ & $\begin{array}{c}2012 \\
\mathrm{n}=2,077 \\
\%\end{array}$ & $\begin{array}{c}2013 \\
\mathrm{n}=1,361 \\
\%\end{array}$ & $\begin{array}{c}2014 \\
\mathrm{n}=1,745 \\
\%\end{array}$ & $\begin{array}{c}\text { Total cases } \\
n=8,384\end{array}$ \\
\hline \multicolumn{7}{|l|}{ Clinical form } \\
\hline Cutaneous & 95.9 & 97.2 & 96.8 & 96.6 & 97.1 & 8,117 \\
\hline Mucosal & 4.1 & 2.8 & 3.2 & 3.4 & 2.9 & 267 \\
\hline \multicolumn{7}{|l|}{ HIV coinfection } \\
\hline Yes & 0.6 & 0.4 & 0.6 & 0.4 & 0.6 & 43 \\
\hline No & 58.0 & 37.2 & 43.8 & 34.4 & 39.8 & 3,492 \\
\hline Unknown & 41.4 & 62.4 & 55.6 & 65.2 & 59.6 & 4,849 \\
\hline \multicolumn{7}{|l|}{ Diagnostic exams } \\
\hline \multicolumn{7}{|l|}{ Direct parasitology } \\
\hline Yes & 86.9 & 88.5 & 87.6 & 89.1 & 90.5 & 7,425 \\
\hline No/not performed & 13.1 & 11.5 & 12.4 & 10.9 & 9.5 & 959 \\
\hline \multicolumn{7}{|l|}{ MIR * } \\
\hline Yes & 10.9 & 5.1 & 6.6 & 5.4 & 4.2 & 511 \\
\hline No & 1.4 & 2 & 2.1 & 1.6 & 1.2 & 143 \\
\hline Not performed & 87.7 & 92.9 & 91.3 & 93.0 & 94.6 & 7,730 \\
\hline \multicolumn{7}{|l|}{ Histopathology } \\
\hline Parasite/compatible finding & 9.5 & 13.3 & 13.7 & 13.5 & 11.3 & 1,191 \\
\hline Not compatible & 4.4 & 2.8 & 3.6 & 2.8 & 2.7 & 7,193 \\
\hline Not performed & 86.0 & 83.9 & 82.6 & 83.9 & 86.0 & 7,068 \\
\hline \multicolumn{7}{|l|}{ Zone } \\
\hline Urban & 52.2 & 45.6 & 43.3 & 48.1 & 46.0 & 3,890 \\
\hline Rural & 45.9 & 50.5 & 53.5 & 49.7 & 51.5 & 4,253 \\
\hline Periurban & 0.4 & 0.3 & 0.2 & 0.5 & 0.6 & 32 \\
\hline Unknown/missing data & 1.5 & 3.6 & 3.0 & 1.6 & 1.9 & 209 \\
\hline \multicolumn{7}{|l|}{ Epidemiological classification } \\
\hline Autochthonous & 75.5 & 83.1 & 82.5 & 79.6 & 84.7 & 6,852 \\
\hline Imported & 24.5 & 16.9 & 17.5 & 20.4 & 15.3 & 1,532 \\
\hline
\end{tabular}

*Montenegro Intradermic Reaction. Source: Information System of Notifiable Diseases (SINAN).

\section{Spatial distribution}

In the spatial distribution analysis, the incidence rate was higher in the municipalities neighboring the town of the State capital, Manaus, as well as in the Southern areas of Amazonas. In 2011 and 2012, the disease was widespread in several municipalities (Figure 2).

Next to the capital, the Municipality of Rio Preto da Eva, had the highest incidence rates $(>1,000$ cases per 100,000 inhabitants throughout the whole period), followed by Presidente Figueiredo, with an incidence rate of 730 and 872 cases per 100,000 inhabitants in 2011 and 2012, respectively. Epidemic outbreaks have also occurred in other municipalities over the years: Tefe in 2011 (central area of
Amazonas) and Caruari and Boca do Acre in 2012 (in the South of Amazonas) (Figure 2).

The following municipalities had the highest incidence per 100,000 inhabitants during the study period: Apui (125, in 2011), Barcelos (139, in 2011), Boca do Acre (202, in 2012), Carauari (210, in 2012), Envira (135, in 2014), Humaita (193, in 2012), Labrea (151, in 2012) and Novo Aripuana (153, in 2012) (Figure 2). Of these, only the Barcelos municipality is not located in the South of Amazonas. Therefore, areas with the highest incidence rates of ATL were the municipalities bordering other states in the South of Amazonas, such as Rondonia, Acre, and Mato Grosso, in which ATL is endemic. 


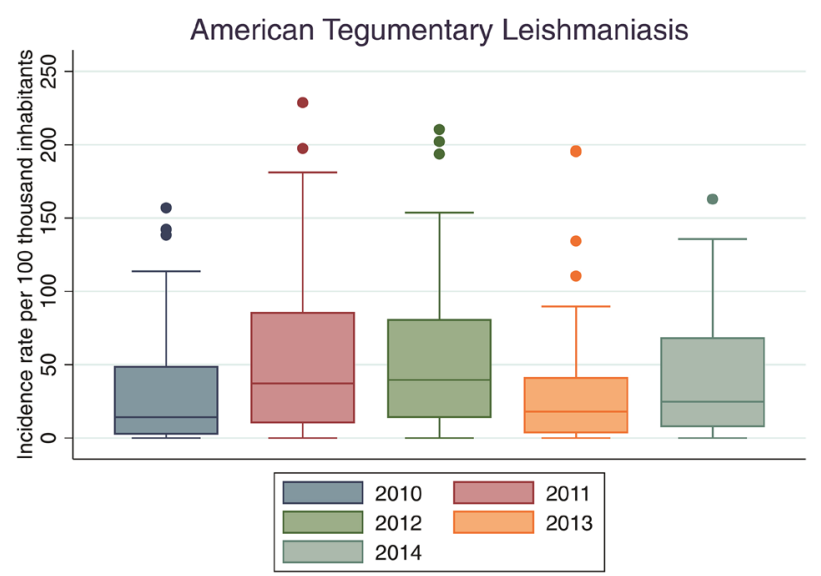

Figure 1 - Incidence rate per 100,000 inhabitants of American Tegumentary Leishmaniasis, Amazonas, 2010-2014. *limited to 200 cases per 100,000 inhabitants, considering the incidence rate from 2010 to 2014 .

\section{DISCUSSION}

The incidence rate of ATL in Amazonas is surprisingly higher than that in other Brazilian States ${ }^{9}$. The epidemiological profile of the cases is almost similar to that from studies conducted in Amazonas and other States ${ }^{13-15}$. However, the age group with the highest prevalence in this study was the one between 20 and 40 years old, which is the most economically productive age group, especially for those who live outside the capital. The occupational profile of ATL is primarily associated with a high incidence of heavy labor activities, such as mining or gold prospecting, farming ${ }^{13,16}$, deforestation for livestock production ${ }^{17}$ and environmental transformations related to increased rural migration $^{18}$.

The following are the possible explanations for the increase in reported ATL cases in the capital of Amazonas, Manaus City, as well as in some municipalities in the metropolitan region of Manaus, such as Rio Preto da Eva and Presidente Figueiredo: access to forest and periurban areas, especially for leisure activities; haphazard occupations ${ }^{19}$ in regions where recent deforestation has occurred; tourism activities and the search for access to health services in the capital, where patients often provide the address of their relatives and acquaintances, and conceal their original addresses, which makes it difficult to report the origin of the cases. Therefore, some individuals may not feel vulnerable to ATL because they live in urban areas or because they lack information about the clinical manifestations, mode of transmission and outcome of the disease, and seek care only when the wound has not healed for some time.

Table 3 - Incidence rate of American Tegumentary Leishmaniasis, according to categories of rate and years, Amazonas, $2010-2014$.

\begin{tabular}{|c|c|c|c|c|c|}
\hline $\begin{array}{l}\text { Category of rate } \\
\text { (interquartile } \\
\text { distribution) }\end{array}$ & 2010 & 2011 & 2012 & 2013 & 2014 \\
\hline \multicolumn{6}{|l|}{ Up to 25} \\
\hline Median & 6.0 & 8.3 & 7.0 & 5.9 & 8.1 \\
\hline (Q1;Q3) & $(0 ; 13.8)$ & $(6.0 ; 16.2)$ & $(0 ; 17.5)$ & $(0 ; 14.8)$ & $(3.6 ; 16.3)$ \\
\hline \multicolumn{6}{|l|}{$>25$ to 50} \\
\hline Median & 36.6 & 35.5 & 28.5 & 35.5 & 28.4 \\
\hline (Q1;Q3) & $(28.4 ; 46.7)$ & $(31.1 ; 44.1)$ & $(27.8 ; 37.5)$ & $(27.1 ; 44.3)$ & $(26.7 ; 38.9)$ \\
\hline \multicolumn{6}{|l|}{$>50$ to 100} \\
\hline Median & 69.2 & 66.2 & 66.1 & 63.7 & 78.0 \\
\hline (Q1;Q3) & $(54.4 ; 76.6)$ & $(54.7 ; 90.1)$ & $(58.3 ; 77.0)$ & $(57.0 ; 79.8)$ & $(64.7 ; 80.0)$ \\
\hline \multicolumn{6}{|l|}{$>100$ to 200} \\
\hline Median & 138.4 & 125.5 & 146.5 & 164.7 & 125.5 \\
\hline (Q1;Q3) & $(113.8 ; 142.3)$ & $(104.4 ; 146.4)$ & $(112.7 ; 152.2)$ & $(122.5 ; 195.5)$ & $(116.3 ; 135.7)$ \\
\hline \multicolumn{6}{|l|}{$>200$} \\
\hline Median & 440.3 & 730.5 & 541.5 & 454.7 & 646.3 \\
\hline (Q1;Q3) & $(353.3 ; 527.3)$ & $(228.7 ; 1032.5)$ & (206.3; 953.9) & $(419.6 ; 489.7)$ & $(534.1 ; 758.5)$ \\
\hline \multicolumn{6}{|l|}{ Total } \\
\hline Median & 14.6 & 41.3 & 44.5 & 18.8 & 25.7 \\
\hline (Q1;Q3) & $(3.8 ; 54.1)$ & $(11.7 ; 90.1)$ & $(16.4 ; 86.9)$ & (3.9; 44.3) & $(8.4 ; 77.7)$ \\
\hline
\end{tabular}

Source: Information System of Notifiable Diseases (SINAN). 


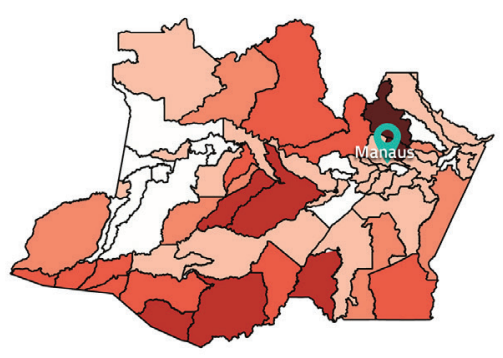

(A)

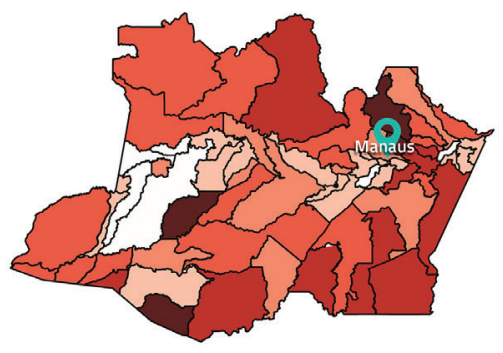

(C)

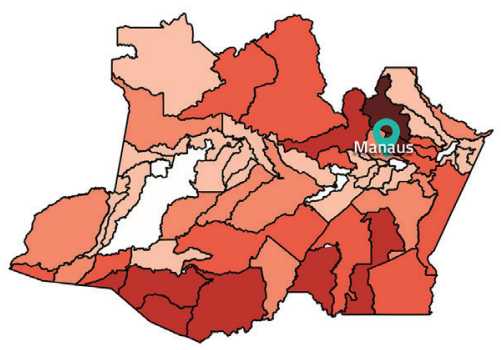

(E)

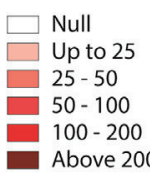

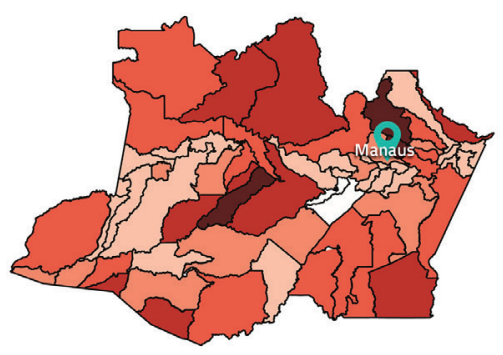

(B)

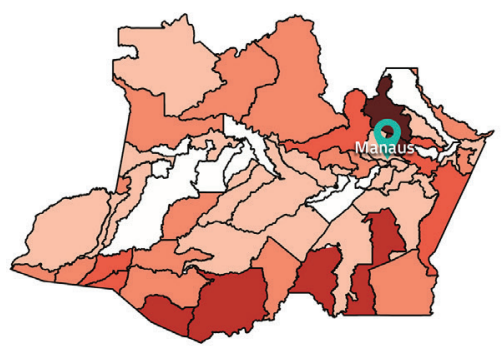

(D)

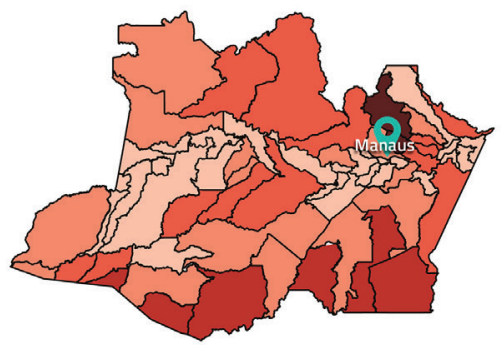

(F)

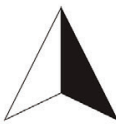

$100 \quad 0 \quad 100 \quad 200 \quad 300 \quad 400 \mathrm{~km}$

Figure 2 - Spatial distribution of incidence rate per 100,000 inhabitants of American Tegumentary Leishmaniasis, Amazonas, 2010 to 2014. A) 2010; B) 2011; C) 2012; D) 2013; E) 2014; F) 2010 to 2014.

Another aspect responsible for neglected ATL, especially among affected people, is that when an individual has an open wound on the skin, he/she may believe that it will heal by itself in time, and usually skin problems are not a priority and are perceived as aesthetic concerns only ${ }^{20}$. This may be an explanation for the persistence of the endemic disease, since the individual may remain infected for a long time without any treatment.

Data from the World Health Organization estimate that Brazil is one of the 10 countries accounting for approximately $87 \%$ of cutaneous leishmaniasis cases worldwide (in 2015) ${ }^{2}$, and our data confirmed the high incidence in Amazonas, with no trend for a decline. This situation calls attention for its potential to lead to severe deformities ${ }^{1}$, which cannot be neglected. In contrast, it is possible to infer that cutaneous leishmaniasis has been efficiently treated, since the cutaneous form occurred in more than $90 \%$ of the reported cases. It is known that the mucosal form only occurs as an ATL complication and further develops into the mucocutaneous form when untreated or neglected ${ }^{20}$. Mucosal ATL is more severe than other forms, responds slowly to treatment, and is more 
susceptible to coinfections. Therefore, early diagnosis through parasitological examination to look for protozoa in supposedly infected tissues is required ${ }^{21,22}$. One can observe, based on this study's results, that the parasitological examination was not performed in all most cases. The lack of parasitological evaluation may prevent early diagnosis and, consequently, compromise proper treatment.

The low proportion of HIV coinfection should also be carefully considered, since the underreporting or lack of specific diagnosis, as evidenced by the high percentage of patients that did not undergo HIV testing may compromise the analysis. ATL progression may be facilitated by HIV coinfection because of decreased immunity. In addition, coinfection demands special ATL treatment; hence, performing an HIV diagnostic test is important, but has been neglected ${ }^{1}$.

In the past, ATL was considered a rural disease, but is currently evident in urban-rural areas ${ }^{16}$, which is consistent with this study's finding that no differences were found between urban and rural areas. This may be due to environmental changes related to migration, urbanization and socioeconomic aspects, leading to large endemic areas and the emergence of outbreaks. Thus, the vectors of ATL also adapt to new environments, approaching the peridomicile, i.e., around dwellings, facilitating disease transmission even in urban areas ${ }^{18}$.

The municipality of residence as the probable infection site, in most situation may suggest the population's migration to periurban areas or even deforestation within the urban areas, which favors contact with vectors; however, the question arises whether the epidemiological investigation, by the surveillance service, is accurate enough to identify the patient's trips to probable sites of infection in an area distant from his or her home. In turn, autochthony facilitates tracking down and effectively diagnosing ATL cases, even in more isolated municipalities.

Although there is expansion in the spatial distribution and an increase in the incidence of ATL in Amazonas, the epidemiological profile has remained similar across the years, suggesting that other factors must be responsible for the increasing spatial and temporal distribution of the disease. Therefore, strategic actions should be implemented in municipalities that have been identified as endemic, in areas that have experienced epidemic outbreaks over the years and in individuals living in risk areas. Therefore, the results presented in this study may guide health institutions or personnel in the formulation of priorities regarding more vulnerable areas and populations. Finally, continuous research should be conducted to detect possible changes in the epidemiological pattern of ATL to support prevention and control strategies.

\section{ACKNOWLEDGMENTS}

The authors would like to thank the National Council for Scientific and Technological Development (CNPq) for supporting this study with a scholarship for scientific initiation (PIB-S/0032/2016) and the Ministry of Health for providing the data used.

\section{AUTHORS' CONTRIBUTIONS}

Maria Jacirema Ferreira Gonçalves, Fernanda Rodrigues Fonseca and Giovana da Costa Teles: conceived the project and designed the research, performed the experiments (data cleaning and preparation of the database), analyzed the data, paper writing and final approval of the manuscript.

\section{CONFLICT OF INTERESTS}

The authors have no conflicts of interest to declare.

\section{FUNDING}

The publication fee of this article was supported by the Instituto Leônidas e Maria Deane of the Fundação Instituto Oswaldo Cruz - Fiocruz.

\section{REFERENCES}

1. Brasil. Ministério da Saúde. Secretaria de Vigilância em Saúde. Coordenação-Geral de Desenvolvimento da Epidemiologia em Serviços. Guia de vigilância em saúde. Brasília: Ministério da Saúde; 2016. [cited 2018 Nov 21]. Available from: http:// portalarquivos2.saude.gov.br/images/pdf/2016/agosto/25/ GVS-online.pdf

2. World Health Organization. Leishmaniasis: situation and trends. [cited 2018 Nov 21]. Available from: http://www.who.int/gho/ neglected_diseases/leishmaniasis/en/

3. Brasil. Ministério da Saúde. Secretaria de Vigilância em Saúde. Departamento de Vigilância das Doenças Transmissíveis. Manual de vigilância da leishmaniose tegumentar. Brasília: Ministério da Saúde; 2017. [cited 2019 Feb 2]. Available from: http://bvsms.saude.gov.br/bvs/publicacoes/manual_vigilancia_ leishmaniose_tegumentar.pdf

4. Araujo AR, Portela NC, Feitosa AP, Silva OA, Ximenes RA, Alves LC, et al. Risk factors associated with American cutaneous leishmaniasis in an endemic area of Brazil. Rev Inst Med Trop Sao Paulo. 2016;58:86.

5. Guerra JA, Maciel MG, Guerra MV, Talhari AC, Prestes SR, Fernandes MA, et al. Tegumentary leishmaniasis in the State of Amazonas: what have we learned and what do we need? Rev Soc Bras Med Trop. 2015;48 Suppl 1:12-9. 
6. Okwor I, Uzonna J. Social and economic burden of human leishmaniasis. Am J Trop Med Hyg. 2016;94:489-93.

7. Instituto Brasileiro de Geografia e Estatística. Cidades e estados: Amazonas. [cited 2019 Mar 12]. Available from: https://www. ibge.gov.br/cidades-e-estados/am.html?

8. Instituto Brasileiro de Geografia e Estatística. Projeção da população das unidades da Federação por sexo e idade: 2000-2030. [cited 2018 Nov 21]. Available from: https:// ww2.ibge.gov.br/home/estatistica/populacao/projecao_da_ populacao/2013/default_tab.shtm

9. Brasil. Ministério da Saúde. Datasus. Leishmaniose tegumentar americana: casos confirmados notificados no sistema de informação de agravos de notificação: Brasil. [cited 2018 Nov 21]. Available from: http://tabnet.datasus.gov.br/cgi/tabcgi. exe?sinannet/cnv/ltabr.def

10. Brasil. Ministério da Saúde. Conselho Nacional de Saúde. Resolução n ${ }^{\circ}$ 510, de 7 de abril de 2016. Diário Oficial da União, Brasília, 24 maio 2016. Seção 1:44-46. [cited 2018 Nov 21]. Available from: http://conselho.saude.gov.br/ resolucoes/2016/reso510.pdf

11. Brasil. Ministério da Saúde. Datasus. População residente: estudo de estimativas populacionais por município, idade e sexo, 2000-2015: Brasil. [cited 2019 Mar 12]. Available from: http:// tabnet.datasus.gov.br/cgi/deftohtm.exe?novapop/cnv/popbr.def

12. Instituto Brasileiro de Geografia e Estatística. Características étnico-raciais da população: um estudo das categorias de classificação de cor ou raça 2008. [cited 2019 Jan 18]. Available from: http://www.ibge.gov.br/home/estatistica/populacao/ caracteristicas_raciais/default_raciais.shtm

13. Rocha TJ, Barbosa AC, Santana EP, Calheiros CM. Aspectos epidemiológicos dos casos humanos confirmados de leishmaniose tegumentar americana no Estado de Alagoas, Brasil. Rev Pan-Amaz Saude. 2015;6:49-54.
14. Figueira LP, Soares FV, Naiff Júnior RD, Vinhote-Silva AC, Silva SS, Espir TT, et al. New human case reports of cutaneous leishmaniasis by Leishmania (Viannia) naiffi in the Amazon region, Brazil. Acta Amaz. 2017;47:47-52.

15. Murback ND, Hans Filho G, Nascimento RA, Nakazato KR, Dorval ME. American cutaneous leishmaniasis: clinical, epidemiological and laboratory studies conducted at a university teaching hospital in Campo Grande, Mato Grosso do Sul, Brazil. An Bras Dermatol. 2011;86:55-63.

16. Benício E, Cordeiro M, Monteiro H, Saboia Moura MA, Oliveira C, Nunes Gadelha EP, et al. Sustained presence of leishmaniasis in urban Manaus, the largest human settlement in the Amazon. Am J Trop Med Hyg. 2015;93:1208-13.

17. Nobres ES, Souza LA, Rodrigues DJ. Incidência de leishmaniose tegumentar americana no norte de Mato Grosso entre 2001 e 2008. Acta Amaz. 2013;43:297-303.

18. Nascimento AP, Alves JB, Cardoso VS, Brito WI. Aspectos epidemiológicos de leishmaniose tegumentar americana no município de Primavera do Leste, Mato Grosso, MT, Brasil. Saude Colet. 2011;8:210-4.

19. Guerra JA, Ribeiro JA, Coelho LI, Barbosa MG, Paes MG. Epidemiologia da leishmaniose tegumentar na Comunidade São João, Manaus, Amazonas, Brasil. Cad Saude Publica. 2006;22:2319-27.

20. Piscopo TV. Mallia Azzopardi C. Leishmaniasis. Postgrad Med J. 2007;83:649-57.

21. Brilhante AF, Melchior LA, Nunes VL, Cardoso CO, Galati EA. Epidemiological aspects of American cutaneous leishmaniasis (ACL) in an endemic area of forest extractivist culture in western Brazilian Amazonia. Rev Inst Med Trop Sao Paulo. 2017;59:e12.

22. Mota LA, Miranda RR. Manifestações dermatológicas e otorrinolaringológicas na Leishmaniose. Arq Int Otorrinolaringol. 2011;15:376-81. 